\title{
MATHEMATICAL REPRESENTATION ABILITY OF JUNIOR HIGH SCHOOL STUDENTS ON SURFACE AREA OF CUBE AND CUBOID
}

\author{
Mardhiyatul Gina ${ }^{1}$, Nia Jusniani ${ }^{2}$, Hedi Budiman ${ }^{3}$ \\ Universitas Suryakancana, Jl. Dr. Muwardi Komplek Pasir Gede Raya, Cianjur, Jawa Barat, Indonesia \\ e-mail: niajusniani56@gmail.com
}

\begin{abstract}
Students still have difficulty in solving contextual math problems. It is because students are not used to solving problems using diverse mathematical representations. The representation can make it easier for students to solve abstract math problems. This study aims to determine and identify the types of errors and factors made by students in mathematical representation ability test questions. This study's subjects were 20 students of class VIII-H at SMPN 1 Cugenang on the Surface Area of Cube and Cuboid. The method used is qualitative. The process of collecting data is observation, written test, interview. The results showed that the level of students' mathematical representation ability based on indicators: (1) was $41 \%$ on the indicator using visual representations to solve problems and make geometrical drawings to clarify problems and facilitate resolution, (2) by $64 \%$ on indicators of problem-solving by involving mathematical expressions, (3) $61 \%$ of indicators create problem situations based on data or representations given. Furthermore, based on the analysis of students' answers in tests on a matter of mathematical representation ability, students making mistakes that are data errors, using definitions or theorems, and technicalities. Factors causing students to make mistakes are forgetfulness, lack of accuracy, learning difficulties, family environment.
\end{abstract}

Keywords: mathematical representation, junior high school students, surface area, cube, cuboid

\begin{abstract}
Abstrak
Siswa masih mengalami kesulitan dalam menyelesaikan masalah matematika yang berbentuk kontekstual. Hal ini diakibatkan siswa tidak biasa menyelesaikan soal dengan menggunakan representasi matematis yang beragam. Representasi dapat mempermudah siswa dalam menyelesaikan masalah matematika yang sifatnya abstrak menjadi lebih nyata. Penelitian ini bertujuan untuk mengetahui dan mengidentifikasi jenis-jenis kesalahan yang dilakukan siswa dalam mengerjakan soal tes kemampuan representasi matematis. Subjek penelitian ini berjumlah 20 siswa kelas VIII-H di SMPN 1 Cugenang pada materi Luas Permukaan Kubus dan Balok. Metode yang digunakan adalah metode kualitatif. Proses pengumpulan data yang dilakukan adalah observasi, tes tertulis, wawancara. Hasil penelitian menunjukkan bahwa tingkat kemampuan representasi matematis siswa berdasarkan indikator (1) sebesar $41 \%$ pada indikator menggunakan representasi visual untuk menyelesaikan masalah dan membuat gambar geometri untuk memperjelas masalah dan memfasilitasi penyelesaian, (2) sebesar $64 \%$ pada indikator penyelesaian masalah dengan melibatkan ekspresi matematis, (3) sebesar $61 \%$ pada indikator membuat situasi masalah berdasarkan data atau representasi yang diberikan. Berdasarkan analisis jawaban siswa dalam tes pada soal kemampuan representasi matematis siswa melakukan kesalahan yaitu kesalahan data, menggunakan definisi atau teorema, dan teknis. Faktor penyebab siswa melakukan kesalahan adalah lupa, kurang teliti, kesulitan belajar, lingkungan keluarga.
\end{abstract}

Kata kunci: representasi matematis, siswa SMP, luas permukaan, kubus, balok

\section{INTRODUCTION}

One of the mathematical abilities that students need to develop in the mathematics learning process is representation ability. Representative skills are also essential in solving problems and communicating. Representation also plays an important role in helping increase students' understanding of mathematical concepts. Representation is the student's ability to communicate mathematical ideas that are learned in a certain way. The various Received: July 4, 2020; Revised: January 1, 2021; Accepted: January 11, 2021 
representations that are often used in communicating mathematical ideas include: diagrams (pictures) or presentations of concrete objects, chart tables, mathematical statements, written text, or a combination of these. Representations can be expressed as internal and external. Thinking about mathematical ideas that are then communicated requires external representations whose forms include verbal, images, and concrete objects. Thinking about mathematical ideas that allow one's mind to work based on these ideas is an internal representation. Representation refers to a result or product that is embodied in the form of a new configuration or construction and involves thinking processes that are carried out to capture and understand the concept, operation, or other mathematical relationships of a configuration. The internal representation is thinking about mathematical ideas that allow one's mind to work based on ideas. According to Jamal (2014: 20), learning difficulties or constraints experienced by students can be caused by internal and external factors, which internal factors are factors that come from within students, for example, health, talent, interest, motivation, intelligence, and so on. External factors come from outside the student, for example, from the school environment, family environment, and community environment. Students' difficulties in learning mathematics include conceptual difficulties, following the opinion of Tall \& Razali (1993), which states that students' mistakes in doing math problems, students experience many misconceptions and understanding in learning.

Based on the results of observations by researchers at SMP Negeri 2 (Junior High School) Ciranjang and interviews with three math teachers, the results of students 'answers in mathematics, especially the students' ability to change contextual questions into mathematical models or change to and solve mathematical problems that require image interpretation and sketches of geometric drawings, are still said pretty low. It can be seen from the answers of many students who make mistakes in answering questions that require mathematical modeling of contextual questions. Besides, it is also supported by the results of the daily test scores of students under the Minimum Completeness Criteria (KKM) which obtain a percentage of completeness with a score above the KKM of $27 \%$.

Based on interviews with five students in class VII at SMPN 2 Ciranjang, it was found that students were not used to learning mathematics, which began with math problems and contextual material, so when students were given contextual questions, students experienced difficulties. Learning in the classroom should provide sufficient opportunities for 
students to be able to practice and develop mathematical representation skills as an important part of problem-solving. Vergnaud (Goldin, 2002) states that representation is an important element in the theory of teaching and learning mathematics, not only because of the use of symbol systems that are important in mathematics, but mathematics also has a role in conceptualizing the real world.

The ability of representation can help students change abstract ideas or ideas into real concepts. Mathematics is abstract ideas, so to make it easier and clearer in solving mathematical problems, mathematical representation skills are needed. NCTM (Jaenudin, 2013) reveals the following: (a) the representation process involves translating problems or ideas into new forms, (b) the representation process including converting diagrams or physical models into symbols or words, and (c) the process representations can also be used to translate or analyze verbal problems in order to make their meaning clear.

This study analyzes students' error analysis in mathematical representation skills Subaidah (2006) in Widodo (2003: 108) states that errors in solving math problems can be divided into three types, namely: concept errors, principle errors, and operational errors. Concept errors are errors in using the concepts related to the material. Misconceptions can occur to students because they are wrong in using the variable's concept to be used. Principle errors are errors relating to the relationship between two or more mathematical objects. Students' mistakes in solving questions, the teacher needs to research and identify the types of student errors and the factors that cause students to make these mistakes.

If students do not understand the concept of a material, it will impact the material to be studied next. Therefore, students have difficulty understanding the material and eventually make mistakes in solving the questions. Poerwadarminta (2003) said, "Wrong means not as it should be, not right, not right, wrong while error means mistakes, deviations from what should have been an error, something wrong, wrong action". Mirza (1998) said that answers that do not match the specified criteria are stated as wrong answers.

Error according to Hadar et al. (1987), among others: (1) Data Errors, (2) Errors in Interpreting Language, (3) Errors Using Logic to Draw Conclusions, (4) Errors Using Definitions or Theorems, (5) Unchecked Solutions, (6) Errors Technical. Errors according to Subanji \& Mulyoto (in Agustina, 2015), the types of errors that students make in doing math problems are as follows. (1) Misconceptions, (2) Errors in Using Data, (3) Language Interpretation Errors, 
(4) Technical Errors, (5) Errors in Drawing Conclusions. Based on the error, according to the experts, the researcher took the error according to (Hadar et al, 1987) by taking three errors: Data Error, Error Using Definition or Theorem, Technical Error.

Students' types of errors in solving math problems need to be known to find the factors that cause students to make these mistakes so that mistakes can be corrected and minimized. According to Ishak and Warji (1987: 19) the factors that can cause student errors in mathematics, namely: (a) Internal factors, namely factors originating from within the student itself, both biological and psychological, for example, intelligence, physical weakness, wrong attitudes and habits in studying the certain subject matter. (b) External factors, namely factors that come from outside the student himself, in the form of the environment, both in the form of a natural environment, for example, a place.

Based on this background, the writer tries to identify students' mistakes in solving problems about the surface area of cube and cuboid by paying attention to indicators of mathematical representation abilities so that similar errors can be minimized and can improve student learning outcomes.

Based on the description previously stated, this research will analyze the mathematical representation ability of junior high school students on the surface area of cube and cuboid. The formulation of this study's problems are: (1) What types of errors do students make in solving math problems on the surface area of cube and cuboid? (2) What factors cause students to make mistakes in solving math problems on cube and cuboid's surface area?

\section{METHODS}

The type of research used in this study is based on a qualitative descriptive approach that aims to describe students' mathematical representation abilities in the cube and cuboid material. The types of data in this study are primary and secondary data. Primary data in this study are the results of written tests and interviews. The results of written tests and interviews were obtained from several students of class VIII-H. Secondary data in this study were all forms of documentation such as lists of student names and documentation during the study.

This research is qualitative, so the data analysis is non-statistical. Qualitative data analysis consisted of three activity lines simultaneously: data reduction, data presentation, 
and drawing conclusions/data verification. This is in line with the stages of analyzing data referring to the Milles \& Huberman model (Gunawan, 2015: 210).

Researchers analyzed the data obtained from students' answers to find errors made by students. The data taken is data from students 'answers based on indicators of errors made by students in answering questions on mathematical representation abilities, based on indicators of students' mathematical representation abilities, and the results of student interviews. The subjects in this study were students of class VIII H at SMP Negeri 1 Cugenang. To determine research subjects, researchers coordinated with the curriculum section's viceprincipal and subject teachers at SMP Negeri 1 Cugenang.

\section{RESULTS AND DISCUSSION}

This study aims to determine the errors in the mathematical representation ability of class VIII students at SMP Negeri 1 Cugenang on the surface area of cube and cuboid. This research was conducted on students of class VIII H, amounting to 20 people as a sample. This research was conducted in March, even semester of the 2019/2020 school year. Data were collected through written tests and interviews during the study. The test is given to students in the form of essays on cube and cuboid's surface area. According to criteria, research data obtained from test results and analyzed based on student errors (Hadar et al. 1987). The data is then analyzed and presented in the form of a description as an illustration of the research results.

In this section, we will describe the results of the research, namely students' errors in working on mathematical representation questions on the material surface area of cube and cuboid based on error criteria according to (Hadar et al, 1987) which includes data errors (misused data), errors using definitions or theorems (distorted definition or theorem), and technical error (technical error).

Below are the question analysis results for the types of errors made by SMPN 1 Cugenang students regarding the mathematical representation ability questions shown in Table 1.

Table 1. Recapitulation of Analysis of Students' Answers to Errors Based on Questions

\begin{tabular}{clc}
\hline \multicolumn{1}{c}{ Question } & \multicolumn{1}{c}{ Indicator } & Total (\%) \\
\hline \multirow{2}{*}{1} & 1. Error Using / Copying Data & $6 \%$ \\
& 2. Errors in Using Formulas & $45 \%$ \\
& 3. Error in Counting & $95 \%$ \\
\hline
\end{tabular}


Average

$49 \%$

$10 \%$

1. Error Using / Copying Data

$90 \%$

$65 \%$

$55 \%$

Average

$35 \%$

1. Error Using / Copying Data

$70 \%$

$95 \%$

$66 \%$

Average

$15 \%$

1. Error Using / Copying Data

$85 \%$

$95 \%$

$65 \%$

$70 \%$

1. Error Using / Copying Data

$60 \%$

$65 \%$

$65 \%$

$55 \%$

$95 \%$

$50 \%$

$67 \%$

Based on Table 1, it can be found that students' errors in answering questions on mathematical representation ability have the highest percentage located in question number 6 by $67 \%$ with an error indicator in using the formula. Meanwhile, the least error with an average of $49 \%$ is located in number 1 with the largest error, namely $95 \%$ with an error indicator in calculating. In line with Eicholz's research (Suparman Pontoh, 2013: 02) also said that the mistakes students often make in solving story problems include wrong in planning what to do and wrong in finding answers through computation (calculation).

Furthermore, the students 'answers to these questions were discussed based on the indicators of students' mathematical representation abilities. The indicator of students' mathematical representation ability used by researchers is based on the criteria according to Villegas (Triono, 2017). The following is a recapitulation table based on the indicators of students' mathematical representation abilities shown in Table 2. 
Table 2. Recapitulation of Students 'Answers Analysis Based on Students' Mathematical Representation Ability Indicators

\begin{tabular}{clcc}
\hline No & $\begin{array}{c}\text { Indicator of Students' Mathematical Representation } \\
\text { Ability }\end{array}$ & Question & Total (\%) \\
\hline \multirow{2}{*}{1} & \multirow{2}{*}{$\begin{array}{l}\text { Use visual representations to solve problems } \\
2\end{array}$} & 1 & $58 \%$ \\
& & 2 & $23 \%$ \\
& & 3 & $66 \%$ \\
\multirow{2}{*}{3} & Problem-solving by involving mathematical expressions & 4 & $61 \%$ \\
& Create problem situations based on the data or & 5 & $61 \%$ \\
& representation provided & 6 & $60 \%$ \\
\hline
\end{tabular}

Based on the results of the analysis of the student's answer recapitulation based on the indicators of students' mathematical representation ability, it was found that the highest student error was in answering question number 3 with problem-solving indicators involving mathematical expressions of $66 \%$. Meanwhile, the least error was made in question number 2, namely $23 \%$, with the indicator using a visual representation to solve the problem. According to Hariati (2016), mathematical representation is very important, especially for communicating ideas; it can make it easier to solve math problems that are being studied by students.

Furthermore, based on the results of the analysis that has been carried out by the researcher on the students' answers in working on the students' mathematical representation ability questions, the results of the students' abilities for each indicator are different, and the percentage of students who answered correctly on each indicator of the mathematical representation ability is shown in Table 3 as follows.

Table 3. Percentage of Students Answering Questions for each Indicator

\begin{tabular}{lc}
\hline \multicolumn{1}{c}{ Indicator } & Percentage of Results for Each Indicator \\
\hline $\begin{array}{l}\text { Use visual representations to solve problems and } \\
\text { draw geometric shapes to clarify problems and } \\
\text { facilitate resolution }\end{array}$ & $41 \%$ \\
$\begin{array}{l}\text { Problem-solving by involving mathematical } \\
\text { expressions } \\
\text { Create problem situations based on the data or } \\
\text { representation provided }\end{array}$ & $64 \%$ \\
\hline
\end{tabular}

Based on Table 3, we can see the percentage per indicator on the problem, the first indicator uses a visual representation to solve the problem and draws geometric shapes to clarify the problem and facilitates the solution obtained by $41 \%$, the second indicator of problem-solving involving mathematical expressions, the percentage result is $64 \%$, and the last indicator creates a problem situation based on the data or representation given the 
percentage shows $61 \%$. Umah's research (2016) found that students had difficulty changing from real problem situations into mathematical representations.

As for what will be explained, namely regarding the analysis of student errors on mathematical communication skills in learning that uses a scientific approach. Based on the results of the students' answers, it was found that the students' answer errors according to the indicators of students' mathematical representation abilities with indicators using visual representations to solve problems and making geometric figures to clarify the problem and facilitate the completion of the percentage results obtained $41 \%$ Furthermore, in problemsolving indicators involving mathematical expressions the results are $64 \%$. In line with the results of research by Shadiq (2004), it is stated that many students in Indonesia have difficulty solving mathematical problems, especially translating problems in everyday life into mathematical models. The third indicator creates a problem situation based on the data or representation provided, that percentage yield is $61 \%$. According to Wijayanti's research (2017), students have difficulty translating questions into a mathematical model and find it difficult to find the steps to solve problems correctly. In contrast to Tias's (2015) results, students' math difficulties lie in the difficulty of remembering, understanding, applying, and analyzing.

Based on the results of the analysis of the answers to students 'errors on the students' mathematical representation ability questions on the surface area of cube and cuboid, it was found that there were three types of errors that were often made by students, namely data errors, errors using definitions or theorems and technical errors. Based on the results of the interview analysis, the factors causing the error can be found. In this study, researchers only analyzed the factors that cause errors in students. There are several factors that cause errors from the results of the interview analysis, and the researcher finds that the factors that cause students to make mistakes are factors from within the first student, namely: students are not used to learning by using pictures and contextual questions, are forgetful, lacking, thorough, and learning difficulties. Meanwhile, the student's external factor is that the family environment influences the student's learning process.

Thus the results of this study indicate that the mathematical representation ability of students at SMPN 1 Cugenang can be said to be low because based on the error analysis according to the indicator of the ability to represent a large percentage, if applying the 
mathematical representation ability is still lacking and as a subject teacher this ability must be applied frequently so that the mathematical representation ability of students especially in school grade VIII so that it can be even better.

So based on previous research by Farida (2015) revealed that the results of his research, the errors made by students were errors to change the information provided into mathematical expressions, students could not determine formulas, the concepts used by students were still wrong, errors in interpreting solutions, not making conclusions, errors in calculations that cause students to make mistakes, namely not paying attention to questions of intention, forgetting formulas, not being familiar with the material, not being given various questions, being rushed, and not being careful in making calculations. There is a similarity between Farida's research, namely in the causes of students making mistakes. Students make several mistakes, one of which is that students cannot determine the formula. Mathematical representation is a substitute form of a mathematical problem situation that is used to find (Syahdi, 2019). Mathematical representations can also be called the result of mathematical ideas that are realized in certain ways, through words, written text, pictures, or symbols to find solutions (Fatqurhohman, 2016).

\section{CONCLUSION}

Based on the analysis of research results on the analysis of student answers and interviews, the researcher can draw conclusions, including: (1) Types of errors made by students of class VIII-H at SMPN 1 Cugenang in the 2019/2020 school year in working on students' mathematical representation ability questions on the surface area of cube and cuboid, there are three types of errors made by students, namely: data errors of $32 \%$, the error using the definition or theorem was $74 \%$, and the technical error was $77 \%$ of the total questions given to students. (2) Factors that cause student's answer errors, among others: Students forget, students are not careful, lazy students cause learning difficulties experienced by students, family environmental factors also affect the learning process of students at school, or home, the care given by parents to students will have a good effect during the learning process.

Based on the results of the research and conclusions, the researchers conveyed some suggestions so that further research on the analysis of students' mathematical representation 
abilities carried out on the surface area of cube and cuboid is suggested to be on other mathematics material, as well as at other levels besides Junior High School (SMP).

\section{REFERENCES}

Agustina, I. R., Mulyono, Asikin, M. (2016). Analisis Kesalahan Siswa Kelas VIII dalam Menyelesaikan Soal Matematika Bentuk Uraian Berdasarkan Taksonomi Solo. Unnes Journal of Mathematics Education, 5(2), 92-100.

Arikunto, S. (2005). Manajemen Penelitian. Jakarta: Rineka Cipta

Farida, N. (2015). Analisis Kesalahan Siswa SMP Kelas VIII Dalam Menyelesaikan Masalah Soal Cerita Matematika. Jurnal Pendidikan Matematika FKIP Universitas Muhammadiyah Metro, 4(2), 42-52. Diakses pada 16 Juni 2020, dari http://fkip.ummetro.ac.id/journal/index.php/matematika/article/view/306/265

Fatqurhohman. (2016). Pemahaman Konsep Matematika Siswa dalam Menyelesaikan Masalah Bangun Datar. Jurnal IImiah Pendidikan Matematika, 4(2), 127-133.

Goldin, A. (2002). Representation in Mathematical Learning and Problem Solving. Dalam English. L.D (Ed) Handbook of International Research in Mathematic Education (pp: 197218). Nahwah, New Jersey: Lawrence Erlbaun Associated Inc.,

Gunawan, I. (2015). Metode Penelitian Kualitatif Teori dan Praktik. Jakarta: Bumi Aksara.

Hadar, M, N., Zaslavsky, O., \& Inbar, S. (1987). An Empirical Classification Model for Errors in High School Mathematics. Journal for Research in Mathematics Education, 18(1), 314.

Hariati, N. (2016). Representasi Matematis Siswa Dalam Memecahkan Masalah Matematika Pada Materi Lingkaran Ditinjau Dari Kemampuan Matematika Di SMPN 5 Sidoarjo. MathEdunesa, 5(3). Januari, vol 18.

Ischak., \& Warji. (1987). Program Remedial dalam Proses Belajar Mengajar. Yogyakarta: Liberty.

Mirza, A. (1998). Analisis Kesalahan Belajar Matematika. Pontianak: FKIP UNTAN.

Pratiwi, W. (2017). Profil Pemecahan Masalah Matematika Kontekstual Siswa SMP Ditinjau dari Tipe Kepribadian Ekstrovert dan Introvert. Jurnal IImiah Pendidikan Matematika, $6(2)$.

Poerwadarminta, W. J. S. (2006). Kamus Umum Bahasa Indonesia. Jakarta: Balai Pustaka. 
Shadiq, F. (2004). Pemecahan Masalah, Penalaran, dan Komunikasi. Departemen Pendidikan Nasional. Yogyakarta.

Syahdi, M. (2019). Peningkatan Kemampuan Representasi Matematis Siswa MI Kota Bengkulu melalui Pembelajaran CMP. Jurnal Pendidikan Matematika Raflesia, 4(1), 73-78. https://doi.org/10.33449/jpmr.v4i1.7532.

Tias, A., \& Wutsqa, D. (2015). Analisis Kesulitan Siswa SMA dalam Pemecahan Masalah Matematika Kelas XII IPA di Kota Yogyakarta. Jurnal Riset Pendidikan Matematika, 2(1), 28-39.

Triono, A. (2017). Analisis Kemampuan Representasi Matematis Siswa Kelas VIII SMP Negeri 3 Tangerang Selatan. Jakarta: Universitas Islam Negeri Syarif Hidayatullah Jakarta.

Umah. (2015). Representasi Matematis Siswa Kelas VIII Terhadap Situasi Nyata Kejadian Dinamis ke dalam Grafik. Universitas Pesantren Tinggi Darul 'Ulum.

Wijayanti, R., \& dkk. (2017). Profil Kesulitan Siswa dalam Memecahkan Masalah Matematika Materi Pokok Bangun Ruang Sisi Datar Ditinjau dari Kecerdasan Visual-Spasial Siswa. Jurnal Pendidikan Matematika dan Matematika (JPMM), 1(4), 129-134.

Widodo, S., A. (2013). Analisis Kesalahan Pemecahan Masalah Divergen Tipe Membuktikan pada Mahasiswa Matematika. Jurnal pendidikan dan pengajaran, 46(2), 106-113. 